\title{
Gentamisin Verilen Sıçanlara Bor Uygulamasının Hematolojik Parametre Düzeylerine Etkileri ${ }^{\#}$
}

\author{
İbrahim DURMUŞ ${ }^{1}$, Sinan İNCE ${ }^{2}$, Mehmet Naci SALİM ${ }^{3}$, \\ Abdullah ERYAVUZ ${ }^{4 *}$, İsmail KÜÇÜKKURT ${ }^{5}$ \\ 1 Afyon Kocatepe Üniversitesi, Șubut MYO, Laborant ve Veteriner Sağh̆ğ, Afyonkarahisar. \\ 2 Afyon Kocatepe Üniversitesi, Veteriner Fakültesi, Farmakoloji ve Toksikoloji AD, Afyonkarahisar. \\ ${ }^{3}$ Afyon Kocatepe Üniversitesi, Veteriner Fakültesi, Arastırma ve Uygulama Çiftliği, Afyonkarahisar. \\ ${ }^{4}$ Afyon Kocatepe Universitesi, Veteriner Fakültesi, Fisyoloji AD, Afyonkarahisar. \\ ${ }^{5}$ Afyon Kocatepe Üniversitesi, Veteriner Fakültesi, Biyokimya AD, Afyonkarabisar.
}

\#Bu çalşsma Afyon Kocatepe Üniversitesi B.A.P. Koordinasyon Birimi tarafindan (proje kodu: 15.VF.08) desteklenmiștir.

*Corresponding author e-mail: eryavuz@aku.edu.tr

\begin{abstract}
ÖZ
Çalışma, gentamisinin yan etkilerinden korunmak için bor (B) kullanımının hematolojik parametrelere etkilerini belirlemek amaciyla yapıldı. Toplamda 56 adet Wistar Albino erkek sıçan her grupta 7 hayvan olacak şekilde 8 gruba rastgele ayrlldı. İlk grup kontrol grubu olarak ayrllırken (borsuz yemle beslendiler), deneme gruplar1 ise, gentamisin (100 mg/kg i.p.), B-5 (5 $\mathrm{mg} / \mathrm{kg} \mathrm{B}$, i.p.), B-10 (10 mg/ $\mathrm{kg} \mathrm{B}$, i.p.), B-20 (20 mg/ $\mathrm{kg}$ B, i.p.), B-5 + gentamisin $(5 \mathrm{mg} / \mathrm{kg}$ B ve $100 \mathrm{mg} / \mathrm{kg}$ gentamisin, i.p.), B-10 + gentamisin $(10 \mathrm{mg} / \mathrm{kg}$ B ve $100 \mathrm{mg} / \mathrm{kg}$ gentamisin, i.p.), B-20 + gentamisin $(20 \mathrm{mg} / \mathrm{kg} \mathrm{B}$ ve $100 \mathrm{mg} / \mathrm{kg}$ gentamisin, i.p.) ş̧eklinde oluşturuldu. Toplam 14 gün süren deneme döneminde, sıçanlara gentamisin enjeksiyonundan 4 gün önce B verilmeye başlandı ve denemenin 14.gününde tamamlandı. Gentamisin uygulamasına 4. gün başlandı ve deneme döneminin 12. gününde bu uygulama sonlandırldı. Denemenin sonunda, hayvanlardan kan örnekleri anestezi altında kalpten alındı. Alınan kan örneklerinde; eritrosit, lökosit ve trombosit saylları ile hematokrit değer, hemoglobin miktar1, ortalama eritrosit hacmi (MCV), ortalama eritrosit hemoglobini $(\mathrm{MCH})$ ve ortalama eritrosit hemoglobin düzeyi (MCHC) belirlendi. Gentamisin lökosit sayısını ve hematokrit değeri düşürdü. Yüksek B uygulaması $(20 \mathrm{mgB} / \mathrm{kg}$ ) lökosit sayısını önemli düzeyde azalttı. Sonuç olarak, bor uygulamasının gentamisinin yol açtığı lökosit sayısındaki azalmayı önlemede etkiye sahip olmadığı kanaatine varıldı.

Anahtar Kelimeler: Bor, Gentamisin, Lökosit, Eritrosit, Trombosit, Hemoglobin.
\end{abstract}

\section{Effects of Boron Administration on Hematological Parameters in Rats Given Gentamicin}

\begin{abstract}
The purpse of this study is to determine the effects of boron (B) utilisation on hematological parameters in order to protect from gentamicin side effects. Totally 56 Wistar Albinomale rats were randomly divided into eight groups containing 7 animal per group. While first group served as a control(fed a diet without boron), experimental groups were as follows; gentamicin group (100 mg/kg, i.p.), B-5 group (5 mg/ $\mathrm{kg} \mathrm{B,} \mathrm{i.p.),} \mathrm{B-10} \mathrm{group} \mathrm{(10} \mathrm{mg/} \mathrm{kg} \mathrm{B,} \mathrm{i.p.),} \mathrm{B-20} \mathrm{group} \mathrm{(20}$ $\mathrm{mg} / \mathrm{kg} \mathrm{B}$, i.p.), B-5 + gentamicin group (5 mg/ $\mathrm{kg}$ B and $100 \mathrm{mg} / \mathrm{kg}$ gentamicin, i.p.), B-10 + gentamicin group (10 mg $/ \mathrm{kg}$ B and $100 \mathrm{mg} / \mathrm{kg}$ gentamicin, i.p.), and B-20 + gentamicin group (20 mg/kg B and $100 \mathrm{mg} / \mathrm{kg}$ gentamicin, i.p.). In experimental period lasted totally 14 days, B application started to be given 4 days before injection of gentamicinto rats and was completed the fourteenth dayof the experiment. Gentamicin started to be given to rats on the fourth day and finished on the twelfth dayof the experiment. In the end of the experiment, the blood samples were taken from the animals by cardiac punctureunder anaesthesia. In the blood smaples, erythrocyte, leukocyte and platelet counts, haematocrite value, hemoglobin concentration, mean cell volume (MCV), mean cell hemoglobin $(\mathrm{MCH})$, mean cell hemoglobine concentration (MCHC) were determined. Gentamicin decreased leucocyte counts and haematocrite value. High boron utilization (20 $\mathrm{mg} / \mathrm{kg} \mathrm{B}$, i.p.) decreased significantly leucocyte counts. In conclusion, the boron supplementation has no a preventive effect on leucocyte counts reduced by gentamicin.
\end{abstract}

Keywords: Boron, Gentamicin, Leukocyte, Erithrocyte, Platelet, Hemoglobin. 


\section{GİRIŞ̧}

Hem toplam spektrumu genişleyen hem de sınıflardaki üye sayıları artıp giderek daha yüksek sayılara ulaşılan antibiyotiklerin hastalıkların tedavisindeki önemleri tartışılmazdır. Bununla birlikte, tedavide esas olarak beklenen etki için kullanilan antibiyotiklerin istenmeyen, beklenmeyen, ters veya yan etkileri de bulunmaktadır. Organizmanın normal fizyolojik fonksiyonların ilgilendiren yan etkiler geniş bir alana yayılmış durumdadır.Aminoglikozid ilaçlar içinde amikasinden sonra, spektrumu en geniş ve antibakteriyel etki gücü en yüksek olan gentamisinin yol açtığı nefrotoksik etki de uzun zamandır bilinmekte (Conzelman, 1980) ve bu etkinin oluşmasında ilacın dozu ve kullanım süresinin de önemli olduğu bildirilmektedir (Lopez-Novoa ve ark., 2011). Nitekim 7 günden fazla gentamisin kullanan hastaların \% 30'unda akut böbrek bozukluğu oluştuğu bildirilmektedir. (PedrazaChaverri ve ark. 2000)

Gentamisinin neden olduğu nefrotoksisitede, vücutta oluşan serbest radikallerin etkisi sonucu membran yapısında bulunan doymamış yağ asidi zincirlerinin moleküler oksijenle etkileşimiyle meydana gelen lipid peroksidasyonunun önemli bir rol oynadığ ifade edilmektedir (Kays ve ark. 1991, Pedraza-Chaverri ve ark. 2000, Küçükkurt ve ark. 2017). Nitekim Ertekin ve ark. (2003), gentamisin verilen köpeklerde zamana bağlı olarak kanda antioksidan vitamin $\mathrm{E}$ düzeyinin azaldığ1 ve lipid peroksidasyonunun en önemli ürünü malondialdehit (MDA) düzeyinin ise arttı̆̆ını gözlemişlerdir. Son yıllarda, gentamisinin yol açtı̆̆ oksidatif strese karş1 antioksidan maddelerin kullanilmasının koruyucu etkilerine yönelik çalışmalar yapılmakta ve stratejiler geliştirilmektedir. $\mathrm{Bu}$ amaca yönelik daha önce yapılan bazı çalışmalarda, gentamisin ile birlikte antioksidan ajanların ve serbest radikal yakalayıcılarının verilmesinin, gentamisine bağlı yan etkileri kısmen azalttı̆̆ veya önlediği gösterilmiştir (Ali ve Bashir 1996, Abdel-Naim ve ark. 1999, Pedraza-Chaverri ve ark. 2000, Ozbek ve ark. 2000, Sayed-Ahmed ve Nagi, 2007, Anandan ve Subramanian, 2012, Küçükkurt ve ark. 2017). Bu bilgi, hastalıkların tedavileri süresince kullanılan gentamisinden kaynaklanabilecek olan oksidatif stres tehdidine karşı bu antibiyotiğe ek olarak hem koruyucu hem de tedavi amaçlı olarak antioksidan uygulamalarının yararlı olabileceğini göstermektedir. Nitekim Anandan ve Subramanian (2012), bir narenciye flavanoidi olan ve antioksidan etkiye sahip hesperidinin, serbest radikal süpürücü etkisiyle sıçanlarda gentamisinin neden olduğu nefrotoksik etkileri azalttığını bulmuşlardır.
İnsan ve hayvanlarda esansiyel bir besin olduğu belirlenmiş (Devirian ve Volpe, 2003, Farfan-Garcia ve ark. 2016) iz minerallerden biri olan ve ülkemizde bol miktarda bulunan bor mineralinin de antioksidan etkilere sahip olduğu (İnce ve ark. 2010) ve gentamisinin neden olduğu oksidatif stresi azalttığ1 (Küçükkurt ve ark. 2017) gösterilmiştir. Biyolojik sahada bor mineralinin kullanılma düzeyine bağlı olarak terapötik ya da toksik etkiler gösterebilmesi nedeniyle insan ve hayvanlarda günlük alınması gerekli miktarının ne olduğuna yönelik bir öneri hala bulunmamaktadır (Pahl ve ark. 2005, Farfan-Garcia ve ark. 2016). Bu yüzden, insan ve hayvanlarda çeşitli besinsel, metabolik ve fizyolojik koşullarda bor mineralinin kaynak ve düzeyinin biyolojik önemini belirlemeye yönelik çalışmalar hala devam etmektedir. Bu çalışmalardan bazilarında da (Farfan-Garcia ve ark. 2016) bilinen bazı ilaçların borla birlikte kullanılmasının, bu ilaçların ilgi ve duyarlılıklarını artırdığı ifade edilmektedir. Nitekim bazı tıbbi bileşiklere bor ilave edildiğinde, bu bileşiklerin etkinliğinde gelişmeler sağlanmıştır (Lesnikovski, 2016). Son yapılan bir araştırmada (Cakir ve ark. 2017), deneysel diyabet oluşturulan sıçanlarda bor uygulamasının kan glikoz düzeyini düşürdüğü ve bazı biyokimyasal parametrelerde yararlı etkilere sahip olduğu tespit edilmiștir. Bor ilave edilen yemlerle beslenen hayvanlarda hematolojik değerlerde de değişimler gözlenmektedir. Protein kısıtlaması yapılmış ve bor ilave edilmiş yemle beslenen ördeklerde, kan hemoglobin düzeyi ve hematokrit değerinin azaldığ1 bildirilmektedir (Hoffman ve ark. 1991). Buna karşın, deneysel bor toksisitesi oluşturulmuş keçilerde ise hemoglobin düzeyinin arttı̆̆1 bulunmuştur (Sisk ve ark. 1990).

Gentamisin uygulamalarının deney hayvanlarında bazı hematolojik değerlerin düzeylerinde de değișiklikler oluşturduğu yönünde bildirimler bulunmaktadır. Gentamisin verilen köpeklerde, lökosit sayısının yükseldiği, buna karşın eritrosit sayıs1 ile hematokrit düzeyinin değişmediği bulunmuştur (Ertekin ve ark. 2003). Bununla birlikte, gentamisin uygulamasının kanda lökosit sayısını azalttığına yönelik bildirimler de bulunmaktadır (Sweetman, 2009, Bustos ve ark. 2016). Oksidatif stresin artmasına yol açan şartlarda eritrosit zar dayanıklılığında azalmanın gözlendiği (Saha ve ark. 2011) ve antioksidanlarla kuvvetlendirmenin eritrosit zar dayanıksızlı̆̆ın yenmede etkili oldukları (Vani ve ark. 2010) bildirilmektedir.

Hematolojik parametreler, gerek hastalık ve metabolik bozuklukların tespit edilmesi gerekse ilaçların yan etkilerinin izlenmesinde rutin olarak ölçülmekte ve bu sayede fizyolojik olaylarda rol 
oynayan mekanizmalarda oluşan değişimler açıklanabilmektedir. Diyetle veya gida takviyesi olarak alınan borun \%84-85'inin idrar ile vücuttan atıldığı ve plazma bor miktarının başlıca renal atılım ile kontrol altında tutulduğu (Kuru ve Yarat, 2017), kronik bor tüketilmesinin ise böbreklerde toksik etkiler doğurabileceği (Pahl ve ark. 2005) bildirimleri dikkate alınırsa, nefrotoksik etkilere sahip gentamisinle birlikte bor uygulamasinin hematolojik parametrelere olas1 etkilerinin ortaya konmas1 önemli olmaktadır. Bu nedenle bu çalışma, gentamisinin oluşturduğu yan etkilerin azaltılması amaciyla antioksidan özelliğinden yararlanmak için değişik düzeylerde i.p. olarak verilen bor mineralinin sıçanların kanında oluşturduğu hematolojik değerlere olan etkilerinin ortaya konması amaciyla yapild1.

\section{MATERYAL ve METOT}

Çalışmada hayvan materyalini AKÜ Deney Hayvanları Araştırma ve Uygulama Merkezinden temin edilen 10-12 haftalık yaşta, 56 adet Wistar Albino erkek sıçan (yaklaşık 150-200 g) oluşturdu. Çalışma boyunca hayvanlara yapilacak tüm müdahaleler Afyon Kocatepe Üniversitesi Deney Hayvanları Yerel Etik Kurulu tarafindan bildirilen kurallar doğrultusunda 21.05.2015 tarihli ve 59 sayılı etik kurul onayı ile gerçekleştirildi. Hayvanların bakımı Afyon Kocatepe Üniversitesi Deney Hayvanları Uygulama ve Araştırma Merkezinde gerçekleştirildi. Çalışmada gentamisin toksikasyonu oluşturmak amaciyla gentamisin sülfat (Sigma, MO, USA) kullanıldı. Tedavi gruplarına uygulanacak B kaynağı olarak daha önceki çalışmalarda antioksidan özelliği gösterilen (Ince ve ark. 2010; 2014) borik asit (Sigma, MO, USA) kullanıldı. Ayrica deneysel çalışma boyunca tüm hayvanlara özel olarak hazırlanan (Bourgeois ve ark. 2007) ve B içermeyen diyet verildi (Tablo 1).

Tablo 1: Çalışmada kullanılan sıçanlara verilen yemin içeriği

Table 1: The composition of basal diet given to rats in the study

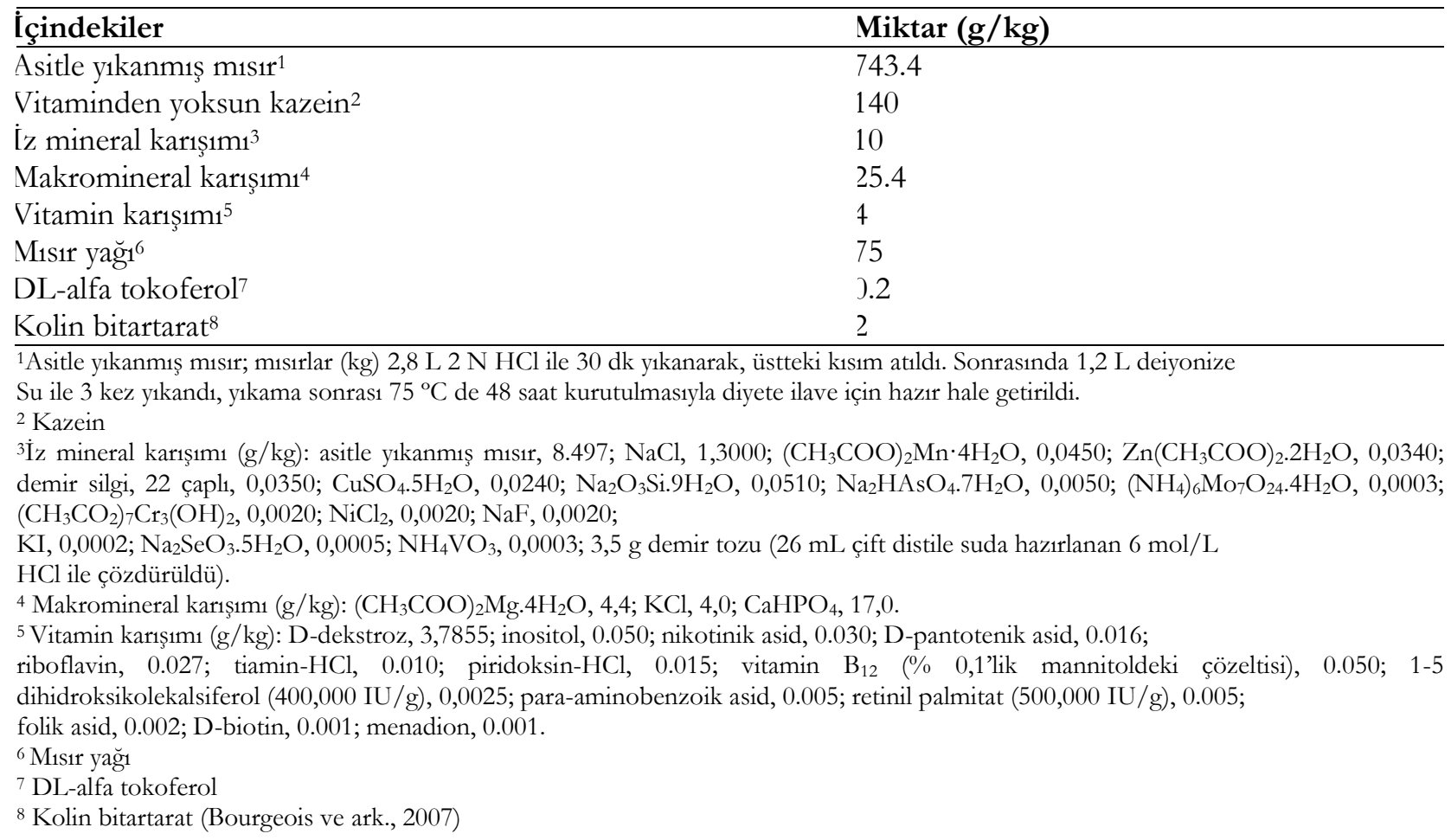

Deneysel aşaması toplam 14 gün süren çalışmada, hayvanlar rastgele örnekleme metodu ile her grupta
7 sıçan olacak şekilde 8 gruba ayrıldı ve çalışmadaki gruplara uygulanan yöntem Tablo 2 verildi. 
Tablo 2. Gruplar, gruptaki hayvan sayıları ve uygulama yöntemi

Table 2. Groups, numbers of animals in groups and the application method

\begin{tabular}{lcc}
\hline \multicolumn{1}{c}{ Gruplar } & Gruptaki hayvan sayıs & Uygulama yöntemi \\
\hline Grup I & 7 & Kontrol \\
Grup II & 7 & $100 \mathrm{mg} / \mathrm{kg}$ Gentamisin sülfat, i.p. \\
Grup III & 7 & $5 \mathrm{mg} / \mathrm{kg} \mathrm{B}$, i.p. \\
Grup IV & 7 & $10 \mathrm{mg} / \mathrm{kg} \mathrm{B}$, i.p. \\
Grup V & 7 & $20 \mathrm{mg} / \mathrm{kg} \mathrm{B}$, i.p. \\
Grup VI & 7 & $5 \mathrm{mg} / \mathrm{kg} \mathrm{B}+100 \mathrm{mg} / \mathrm{kg}$ gentamisin sülfat, i.p. \\
Grup VII & 7 & $10 \mathrm{mg} / \mathrm{kg} \mathrm{B}+100 \mathrm{mg} / \mathrm{kg}$ gentamisin sülfat, i.p. \\
Grup VIII & 7 & $20 \mathrm{mg} / \mathrm{kg} \mathrm{B}+100 \mathrm{mg} / \mathrm{kg}$ gentamisin sülfat, i.p. \\
\hline
\end{tabular}

Bor kaynağ1 olarak serum fizyolojik içinde çözdürülerek hazırlanan borik asit 5,10 ve 20 $\mathrm{mgB} / \mathrm{kg}$ dozlarda periton içi (i.p.) yolla (Ince ve ark., 2014) 3., 4. ve 5. gruplarda bulunan sıçanlara 14 gün süreyle ve borik asit 5,10 ve $20 \mathrm{mgB} / \mathrm{kg}$ dozlarda periton içi(i.p.) yolla 6., 7. ve 8. gruptaki sıçanlara gentamisin enjeksiyonundan 4 gün önce verilmeye başlandı ve gentamisin uygulamasının bitişinden itibaren 2 gün daha verildi (Tablo
2).Enjeksiyona hazır hale getirilen gentamisin ise $100 \mathrm{mg} / \mathrm{kg}$ dozda 2., 6., 7. ve 8.gruplardaki hayvanlara B uygulamasindan sonra 4. günde i.p. yolla verilmeye başlandı ve 8 gün boyunca günde tek doz halinde uygulandı (Tablo 2). Çalışmanın 14. günü gecesi sıçanlar aç bırakıldı ve 12 saat açlık sonrası ketamin $(65 \mathrm{mg} / \mathrm{kg}$, i.p.) - ksilazin $(7 \mathrm{mg} / \mathrm{kg}$, i.p.) anestezisi altında deney hayvanlarından analizler için gerekli kan örnekleri alındı.

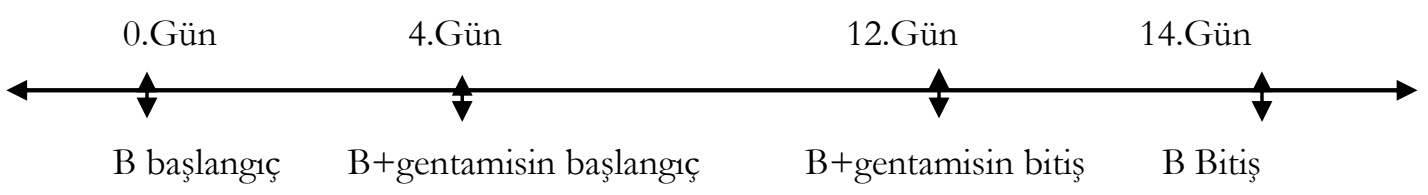

Alınan kan örneklerinin Afyon Kocatepe Üniversitesi, Veteriner Fakültesi, Veteriner Sağllk Uygulama ve Araştırma Merkezi'nde bulunan kan sayım cihazında (Mindray BC2800 VET, Çin) ölçümleri yapılarak; lökosit (WBC), eritrosit (RBC) ve trombosit (PLT) saylar1, hemoglobin ( $\mathrm{Hb})$ miktar1, hemotokrit (Hct) değer ile ortalama eritrosit hacmi (MCV), ortalama eritrosit hemoglobini $(\mathrm{MCH})$ ve ortalama eritrosit hemoglobin düzeyi (MCHC) değerleri belirlendi.

Araşturmadan elde edilen sonuçlar, SPSS 20,0 istatistik paket programinda tek yönlü ANOVA testi uygulanarak yapildi. İstatistiksel fark bulunan sonuçlara Duncan testi uyguland, veriler "ortalama \pm standart sapma" olarak ifade edildi. İstatistiksel anlamllık için $\mathrm{p}<0.05$ kabul edildi.

\section{BULGULAR}

Çalışmada tüm gruplarda elde edilen RBC, WBC, $\mathrm{Hb}, \mathrm{Hct}, \%$ lenfosit, \% monosit, \% granulasit, MCV, MCH, MCHC ve PLT'e yönelik veriler Tablo 3'de verilmiştir. Çalışmada gentamisin uygulamasının sıçanlarda lökosit sayısı ve Hct değeri istatistiksel açıdan önemli $(\phi<0.05)$ düzeyde düşürdüğü ancak diğer incelenen parametrelere etkisinin olmadığ düzeyde B uygulamasının ise sadece $20 \mathrm{mg} / \mathrm{kg}$ düzeyinde B uygulamasının lökosit sayısını istatistiksel anlamda önemli $(\phi<0.05)$ düzeyde düşürdüğü ancak diğer düşük $B$ düzeylerinin incelenen parametrelere etkilerinin olmadığ tespit edildi (Tablo 3). Gentamisinin neden olduğu lökosit sayısındaki azalmayı, gentamisin verilen hayvanlara uygulanan bor düzeylerinden hiç birinin düzeltemediği gözlenirken, Hct düzeyindeki azalmanın B uygulamaları ile önlendiği saptandı. 
Tablo 3. Erkek sıçanlarda $100 \mathrm{mg} / \mathrm{kg}$ dozunda gentamisin (Gen), 5, 10 ve $20 \mathrm{mgB} / \mathrm{kg}$ düzeylerindeki borun B) ve $100 \mathrm{mg} / \mathrm{kg}$ Gen +5 (B-5), 10 (B-10) ve 20 (B-20) mg/ $\mathrm{kg}$ miktarlarında bor uygulamasının kan parametrelerine etkisi

Table 3. The effects of gentamicin at dose $100 \mathrm{mg} / \mathrm{kg}$, boron at levels of 5, 10 and $20 \mathrm{mgB} / \mathrm{kg}$ and gentamicin $(100 \mathrm{mg} / \mathrm{kg})$ plus boron $(5,10$ and $20 \mathrm{mgB} / \mathrm{kg})$ on hematological parameters in male rats

\begin{tabular}{|c|c|c|c|c|c|c|c|c|}
\hline & KONTROL & Gen & B- 5 & B-10 & B-20 & B-5+Gen & B-10+Gen & B-20+Gen \\
\hline $\begin{array}{c}\text { WBC } \\
\left(\mathrm{x} 10^{3} / \mu \mathrm{L}\right)\end{array}$ & $.44 \pm 2.41^{\mathrm{a}}$ & $5.11 \pm 1.94^{b}$ & $9.05 \pm 3.81^{\mathrm{a}}$ & $3.11 \pm 3.03^{\mathrm{ab}}$ & $8.00 \pm 2.21^{b}$ & $5.67 \pm 1.44^{b}$ & $5.72 \pm 2.95^{b}$ & $6.55 \pm 1.06^{\mathrm{b}}$ \\
\hline LENF\% & $75.48 \pm 6.74$ & $77.31 \pm 8.41$ & $77.75 \pm 4.13$ & $75.48 \pm 5.36$ & $75.65 \pm 4.52$ & $78.71 \pm 4.49$ & $75.70 \pm 9.74$ & $71.03 \pm 8.02$ \\
\hline MON\% & $3.64 \pm 0.90$ & $4.32 \pm 0.92$ & $3.71 \pm 2.72$ & $3.91 \pm 0.34$ & $3.95 \pm 2.09$ & & $3.91 \pm 0.34$ & $3.58 \pm 0.87$ \\
\hline & $20.70 \pm 4.18$ & $29.10 \pm 8.11$ & $21.60 \pm 3.78$ & $24.05 \pm 9.98$ & $24.98 \pm 4.37$ & $21.60 \pm 2.78$ & $22.50 \pm 3.78$ & $23.06 \pm 9.23$ \\
\hline $\begin{array}{c}\text { RBC } \\
\left(\times 10^{6} / \mu \mathrm{L}\right)\end{array}$ & $7.74 \pm 0.51$ & $6.78 \pm 0.73$ & $7.23 \pm 1.03$ & $7.22 \pm 0.72$ & $7.09 \pm 0.76$ & & $7.22 \pm 0.70$ & $7.33 \pm 0.35$ \\
\hline $\begin{array}{l}\text { HGB } \\
\text { (g/dl) }\end{array}$ & $13.50 \pm 1.52$ & $15.22 \pm 1.00$ & $13.85 \pm 1.23$ & $13.84 \pm 0.87$ & $13.98 \pm 1.20$ & $14.77 \pm 1.21$ & $14.77 \pm 1.21$ & $14.25 \pm 1.92$ \\
\hline $\begin{array}{c}\text { HCT } \\
(\%)\end{array}$ & $39.52 \pm 2.91^{\mathrm{a}}$ & $32.60 \pm 3.11^{\mathrm{b}}$ & $38.74 \pm 4.15^{a}$ & $37.47 \pm 3.82^{\mathrm{a}}$ & $37.20 \pm 4.22^{\mathrm{a}}$ & $38.46 \pm 4.64^{a}$ & $38.60 \pm 3.09 a$ & $38.47 \pm 3.52^{a}$ \\
\hline $\begin{array}{c}\text { MCV } \\
\left(\mu^{3}\right)\end{array}$ & $57.60 \pm 1.50$ & $55.68 \pm 0.66$ & $57.20 \pm 1.36$ & $57.52 \pm 1.22$ & $55.42 \pm 2.30$ & $55.60 \pm 4.21$ & $56.52 \pm 1.12$ & $54.41 \pm 1.44$ \\
\hline $\begin{array}{c}\text { MCH } \\
(\mathrm{pg})\end{array}$ & $19.62 \pm 0.39$ & $19.90 \pm 0.48$ & $20.42 \pm 0.48$ & $20.44 \pm 0.56$ & $19.74 \pm 0.78$ & $19.66 \pm 1.86$ & $20.44 \pm 0.56$ & $19.68 \pm 0.57$ \\
\hline $\begin{array}{c}\text { MCHC } \\
(\%)\end{array}$ & $35.15 \pm 0.36$ & $35.86 \pm 0.87$ & $35.80 \pm 1.33$ & $35.61 \pm 1.10$ & $35.71 \pm 0.96$ & $36.08 \pm 1.41$ & $35.61 \pm 1.10$ & $36.95 \pm 1.29$ \\
\hline $\begin{array}{c}\text { PLT } \\
\left(\mathrm{x} 10^{5} / \mu \mathrm{L}\right)\end{array}$ & $11.32 \pm 1.85$ & $12.11 \pm 3.07$ & $12.48 \pm 2.64$ & $9.66 \pm 4.10$ & $14.04 \pm 3.50$ & $14.60 \pm 1.96$ & $9.66 \pm 4.10$ & $11.17 \pm 3.03$ \\
\hline
\end{tabular}

Ortalama \pm standart sapma; $\mathrm{n}=7$

a,b,c,d,e: Aynı satırda farklı harfleri taşıyan değerler istatistiksel olarak önemlidir $(p<0.05)$. WBC: Lökosit, LENF: lenfosit, MON: monosit, GRAN: granulosit, RBC: Eritrosit, HGB: hemoglobin, HCT: hemotokrit, MCV: ortalama eritrosit hacmi, MCH: her bir kırmız1 kan hücresindeki ortalama hemoglobin, MCHC: belli bir miktar kırmızı kan hücresindeki hemoglobin yoğunluğu, PLT: trombosit

\section{TARTIŞMA}

Tüm canlilarda hematolojik ve biyokimyasal parametrelerdeki değişimler; pek çok klinik ve subklinik hastalıkların ayırıc1 tanısı, şiddetinin belirlenmesi, seyrinin takibi ve tedavinin ulaştı̆ı düzeyin tespiti ile vücuttaki metabolik olayları ve organların fonksiyonlarını yansitması bakımından hekimlere ve araştırıcilara önemli bilgiler vermektedir (NseAbasi ve ark. 2014). Ayrica, hematolojik değerlerde meydana gelen değişimler, sağlıklı yaşamın kontrol programları içerisinde ve çevre ile beslemenin kan yapan organlara etkisinin göstermesinde de başvurulan parametreler arasindadir (Lewis, 1990, NseAbasi ve ark. 2014). Bununla birlikte, değişik hayvan türleri kullanılarak yapılan toksikolojik çalışmalarda da ilaçların yan etkilerini belirlemek ve izlemek için hematolojik parametrelerdeki değişimler incelenmektedir (Başoğlu ve ark. 2010).

Hastalıkların tedavisindeki önemleri nedeniyle antibiyotiklerin ve bunların yan etkilerini azaltmak ya da yok etmek için kullanılan maddelerin hematolojik değerlerde meydana getirdiği istenmeyen veya beklenmeyen yan etkilerinin tespit edilmesi, ilgili antibiyotiğin ve birlikte kullanılan maddenin tedavide kullanılmasındaki seçenek bakımından değerlendirilmesinde hekimlere ve araştırıcılara önemli bilgiler sunacaktır. $\mathrm{Bu}$ çalısmada; aminoglikozid yapılı bir antibiyotik olan gentamisinin yüksek dozda ve uzun süre kullanılmasına bağlı olarak nefrotoksisite gelişmesinin yüksek olduğu bildirimlerinden (Ateşşahin ve ark. 2003, Anandan ve Subramanian, 2012) hareketle siçanlara $100 \mathrm{mg} / \mathrm{kg}$ doz düzeyinde gentamisin 7 gün süreyle uygulanmış ve gentamisin uygulaması ile antioksidan özelliğe sahip bor mineralinin birlikte kullanılmasına bağlı olarak hematolojik değerlerdeki değişimleri ele alınmıştır. Çalışmada kullanılan borik asit düzeyleri, sıçanlarda üreme ve gelişmede yan etkilerin gözlenmediği bildirilen (Farfan-Garcia ve ark. 2016) düzeyler (sırasıyla $9.6 \mathrm{mgB} / \mathrm{kg} /$ gün ve $17.5 \mathrm{mgB} / \mathrm{kg} /$ gün) dikkate alınarak 5,10 ve $20 \mathrm{mg} / \mathrm{kg}$ olarak belirlendi. 
Yang1sal reaksiyonların anahtar özelliklerinden biri de, doku hasarının oluştuğu bölgeye lökosit takviyesinin yapılmasıdır. Bazı antibiyotiklerin serbest radikal üretimini artırarak lökositler (Páez ve ark., 2008) ve tüm kanda (Correa-salde ve Albesa, 2009) olumsuz etkiler gösterdiği, gentamisinin de benzer şekilde etkiler göstererek lökopeniye yol açtığ1 (Sweetman, 2009) ifade edilmektedir. Nitekim Bustos ve ak. (2016), in vitro insan lökositlerinde gentamisinin serbest radikal üretimini artırdığını göstermişlerdir. $\mathrm{Bu}$ çalışmada, gentamisin uygulamasına bağlı olarak kan lökosit sayısındaki azalmanın araştırıcıların (Bustos ve ark., 2016) bulgularını desteklediği gözlendi. Bununla birlikte, çalışmada elde edilen bu bulgu, köpeklerde gentamisin uygulaması öncesine göre uygulamanın 5. gününden 10.gününe kadar kanda lökosit sayısının arttığ1 yönündeki bildirimle (Ertekin ve ark., 2003) ters olduğu gözlendi. Araştırıcılar (Ertekin ve ark. 2003) lökosit sayısındaki uygulama sonrası 2. günde önemsiz olmasina rağmen 5.günden itibaren meydana gelen artışın, strese bağlı olarak şekillenebileceğini öne sürmüşlerdir. Ertekin ve ark. (2003), köpeklerde nefrotoksikozis oluşturmak amaciyla, her sekiz saatte bir ve günde üç kez olmak üzere toplam 10 gün süreyle 15 $\mathrm{mg} / \mathrm{Kg}$ dozunda kas içi yolla gentamisin uygulaması yapmışlardır. Bu çalışmada elde edilen bulgular, toksik etki yaptığı bildirilen (Ateşşahin ve ark., 2003) ve sıçanlarda nefrotoksik etkiler oluşturduğu gösterilen (Anandan ve Subramanian, 2012) gentamisinin $100 \mathrm{mg} \mathrm{/} \mathrm{kg}$ doz düzeyinin kullanılmasına bağlı şekillenmiş olabilir. Diğer yandan, tavşanlarda gentamisin uygulamasının lökosit sayısını azalttığ1 yönündeki bildirimle (Corrigan ve Bell, 1971) uyumlu olarak sunulan çalışmada yüksek düzeyde gentamisin uygulaması kanda lökosit sayısını azaltmıştır. Bununla birlikte, gentamisin uygulanan grupta elde edilen lökosit sayıları, sıçanlarda bildirilen (Kaya ve Çenesiz, 2010) normal sayıların $\left(3-17 \times 10^{3} / \mathrm{mm}^{3}\right)$ arasında olduğu gözlemlendi.

Gentamisin uygulanan sıçanlarda gözlenen lökosit sayısındaki azalma, gentamisinin hücre içi oksidatif stres artışına yol açmasından dolayı kaynaklanmış olabilir(Becerra ve ark. 2003, Küçükkurt ve ark., 2017). Nitekim, reaktif oksijen türlerinin üretimindeki aşırı artışın doku hasarına yol açabileceği ifade edilmektedir (İnce ve ark., 2010). $\mathrm{Bu}$ çalışmada, antioksidan özelliğe sahip olduğu gösterilen (İnce ve ark. 2010, Küçükkurt ve ark., 2017, Cakir ve ark., 2017) bor minerali verilen gruplarda borun uygulama doz miktarı arttıkça,lökosit sayısında azalma olduğu tespit edildi. $\mathrm{Bu}$ azalmanın sıçanların gelişmesinde borik asidin yan etki göstermediği ifade edilen (Farfan-Garcia ve ark. 2016) düzeyin (17,5 mg/kg/gün) üzerindeki düzeydeki $(20 \mathrm{mg} / \mathrm{kg})$ ilavede istatistiksel anlamda önemli olduğu gözlemlendi (Tablo 3). Nitekim sıçanlarda $15 \mathrm{mg} / \mathrm{kg}$ gün bor oral olarak verildiğinde lökosit sayısının etkilenmediği bildirilmektedir (Yildirım ve ark. 2017).

Gentamisin+bor uygulamasinin da gentamisinin neden olduğu lökosit sayısındaki azalmaya etkisinin olmadığ1 bulundu. $\mathrm{Bu}$ bulgu, bor mineralinin antioksidan etkisinin lökositleri korumaya yetecek yeterlilikte olmadığ1 gibi bizzat kendisinin de yüksek dozda kullanılmasının olumsuz etki gösterdiğine işaret etmektedir. Bor mineralinin yüksek dozlarda lökositlere olan olumsuz etkisinin nedenlerini ortaya çıkarabilecek daha fazla çalışmaya ihtiyaç bulunmaktadir.

Çalışmada, sıçanlara gentamisin ile birlikte bor minerali uygulamasının lökosit yüzde oranlarına etkisinin olmadı̆̆1 gözlendi. Bustos ve ark. (2016), yaptıkları in vitro çalışmalarında gentamisin uygulamasına bağlı serbest radikal üretiminin polinükleer lökositlerde mononükleer lökositlere göre iki kat daha yüksek olduğunu gözlemişler ve başlica nötrofiller olmak üzere polinükleer lökositlerin mononükleer lökositlere göre gentamisin uygulamasina bağlı olarak daha fazla serbest radikal üretmeye yönelik uyarıldıklarını ileri sürmüşlerdir. Benzer şekilde, makrolid grubu antibiyotiklerin oksidatif patlamada ve apoptoziste değişiklikler oluşturarak nötrofiller üzerinde direk etki oluşturabildikleri de ifade edilmektedir (Altenburg ve ark. 2011). Bu çalişmada, gerek gentamisin uygulamasinin gerekse bor uygulamasının granülositler ile monosit ve lenfosit düzeylerinin yüzde oranlarına istatistiksel önemde bir etkisinin olmadığı bulundu. Bu çalışmada in vivo elde edilen bu bulgular ile araştırıcıların (Bustos ve ark. 2016) in vitro bildirimleri arasındaki farkın deneme metodundan kaynaklanabileceği ileri sürülebilir.

Çalışmada hem gentamisin hem de bor uygulamalarının eritrosit sayısı ve hemoglobin düzeylerine etkisinin olmadı̆̆1, gentamisin uygulamasının ise hematokrit düzeyini azalttığ1 ancak bor ilavesinin bu azalmayı önlediği bulundu. $\mathrm{Bu}$ bulgu, protein kısıtlaması yapılmış ve bor ilave edilmiş yemle beslenen ördeklerde, kan hemoglobin düzeyi ve hematokrit değerinin azaldığ1 bildirimi (Hoffman ve ark. 1991) ile deneysel bor toksisitesi oluşturulmuş keçilerde hemoglobin düzeyinin arttığı yönündeki bildirimle (Sisk ve ark. 1990) farklılık arz etmiştir. Bunun nedeni çalışmalarda kullanılan bor mineralin düzeyi, kaynağ1 ve denemede kullanılan hayvan türlerinin farklı olmasından kaynaklanabilir (Farfan-Garcia ve ark. 2016). Nitekim lityum bor verilen sıçanlarda (Yıldırım ve ark. 2017) ve boraks verilen tavşanlarda (Başoğlu ve ark. 2010) eritrosit sayısı, hemoglobin miktarı ve hematokrit değer ile 
platelet sayısının etkilenmediği bildirilmektedir. Bu çalışmada elde edilen eritrosit sayısı, hemoglobin miktarı, hematokrit değer ile ortalama eritrosit hacmi (MCV), ortalama eritrosit hemoglobini $(\mathrm{MCH})$, ortalama eritrosit hemoglobin düzeyi (MCHC) ve platelet sayısı; sıçanlarda bildirilen (Kaya ve Çenesiz, 2010) normal (sırasiyla 510x106/mm³, 11-18 g/dl, \%36-57,46-65 fl, 11,9-19,0 pg, 25,9-35,1 g/dl ve 500-1300x103/ $\mathrm{mm}^{3}$ ) değerlere yakin ya da arasinda bulunmuştur.

\section{SONUÇ}

Çalışmada; hem gentamisin uygulamasının hem de bor mineralinin bu çalışmada kullanılan yüksek düzeyinin yol açtığı lökosit sayısındaki azalma nedeniyle, vücudun savunmasinda önemli fonksiyona sahip lökositlerin işlevlerinde olumsuz etkilerinin olabileceği söylenebilir. Bu nedenle, antibakteriyel ilaç olarak gentamisin tedavide kullanılacağında, sadece bakterilerin duyarlılığı değil aynı zamanda konakçı savunma sistemine olan etkileri de göz önünde tutulmalıdır. Çalışmada bor uygulamasına yönelik elde edilen bulguların, borun insan ve hayvanlarin hem fizyolojik fonksiyonlarında oluşturduğu etkilerin mekanizmasını açıklamaya hem de günlük diyetle alınması gerekli düzeyinin belirlenmesine katkı sağlayacağı kanaatine varıldı.

\section{KAYNAKÇA}

Abdel-Naim AB, Abdel-Wahab MH, Attia FF. Protective effects of vitamin $\mathrm{E}$ and probucol against gentamicin-induced nephrotoxicity in rat. Pharmacol. Res.1999; 40: 183-187.

Ali BH, Bashir AK. Effect of superoxide dismutase treatment on gentamicin nephrotoxicity in rats. Gen. Pharmacol 1996; 27: 349-353.

Altenburg J, de Graaf C, van der Werf T, Boersma W. Immunomodulatory effects of macrolide antibiotics. part 1: biological mechanisms. Respiration 2011; 81: 67-74.

Anandan R, Subramanian P. Renal protective effect of hesperidin on gentamicin-induced acute nephrotoxicity in male Wistar albino rats. Redox Report 2012; 17: 219-226.

Atessahin A, Karahan I, Yilmaz S, Çeribaşi AO, Princci I. The effect of manganese chloride on gentamicin-induced nephrotoxicity in rats. Pharmac. Res. 2003; 48: 637-642.

Basoglu A, Baspinar N, Ozturk AS, Akalin PP. Effects of boron administration on hepatic steatosis, hematological and biochemical profiles in obese rats. Trace Elem. Electrol. 2010; 27: 225-231.

Becerra MC, Eraso AJ, Albesa I. Comparison of oxidative stress induced by ciprofloxacin and pyoverdin in bacteria and in leukocytes to evaluate toxicity. Lumin 2003; 18: 334 340 .

Bourgeois AC, Scott ME, Sabally K, Koski KG. Low dietary boron reduces parasite (nematoda) survival and alters cytokine profiles but the infection modifies liver minerals in mice. J. Nutr. 2007; 137: 208086.

Bustos PS, Deza-Ponzio R, Páez PL, Albesa I, Cabrera J, Virgolini MB, Ortega MG. Protective effect of quercetin in gentamicin-induced oxidative stress in vitro and in vivo in blood cells. Effect on gentamicin antimicrobial activity. Environ. Tox. Pharm. 2016; 48: 253-264.

Cakir S, Eren M, Senturk M, Sarica ZS. The effect of boron on some biochemical parameters in experimental diabetic rats. Biol. Trace Elem. Res. 2017. https://doi.org/10,1007/s12011-017-11820 Erișim Tarihi: 15.03.2018

Conzelman GM. Pathogenesis of Renal Failure due to Aminoglicosides and Contrast Media Used in Roentgenography. Am. J. Med. 1980; 69: 767-774.

Correa-salde V, Albesa I. Reactive oxidant species and oxidation of protein and heamoglobin as biomarkers of susceptibility to stress caused by chloramphenicol. Biomed. Pharmacother. 2009; 63: 100-104.

Corrigan JJ, Bell BM. Comparison between the polymyxins and gentamicin in preventing endotoxin-1nduced intravascular coagulation and leukopenia. Infect. Immunit. 1971; 5: 563-566.

Devirian TA, Volpe SL. The physiological effects of dietary boron. Critical Reviews in Food Science and Nutrition 2003; 43(2): 219-231.

Ertekin A, Karaca M, Akkan HA, Cemek M, Ormanc1 N. Köpeklerde gentamisin nefrotoksikozisinde lipit peroksidasyonu, antioksidan maddeler, antioksidan vitaminler ve bazı hematolojik-biyokimyasal parametre düzeylerinin araştırılması. Tr. J. Vet. Anim. Sci. 2003; 27: 535-540.

Farfan-Garcia ED, Castillo-Mendieta NT, Ciprés-Flores FJ, Padilla-Martínez II, Trujillo-Ferrara JG, Soriano-Ursúa, MA. Current data regarding the structure-toxicity relationship of boron-containing 
compounds. Toxicol. Letters 2016; 258: 115-125.

Hoffman DJ, Sanderson CJ, Le Captain LJ, Cromatie E, Pendleton GW. Interactive effects of boron, selenium, and dietary protein on survial, growth, and physiology in mallard ducklings. Arch. Environ. Contam. Toxicol. 1991; 20: 288-294.

İnce $\mathrm{S}$, Kucukkurt $\mathrm{I}$, Cigerci IH, Fidan AF, Eryavuz A. The effects of dietary boric acid and borax supplementation on lipid peroxidation, antioxidant activity, and DNA damage in rats. J. Trace Elem. Med. Biol. 2010; 24: 161-164.

Ínce S, Kucukkurt I, Demirel HH, Acaroz DA, Akbel E, Cigerci, IH. Protective effects of boron on cyclophosphamide induced lipid peroxidation and genotoxicity in rats. Chemosphere 2014; 108: 197-204.

Kaya M, Çenesiz M. Deney hayvanlarının fizyolojisi. In: Aksoy A, Kolbakır F, Hökelek M editors. Laboratuvar hayvanlar1. Ondokuz Mayıs Üniversitesi Yayınları 2010; p.42.

Kays SE, Crowell WA, Johnson MA. Iron supplementation increase gentamisin nephrotoxicity in rats. J Nutr 1991; 121: 1869-1875.

Kuru R, Yarat A. Bor ve sağlığımıza olan etkilerine güncel bir bakiş. Clin. Exp. Health Sci. 2017; 7,(3): 107-114.

Küçükkurt İ, Arslan-Acaröz D, Demirel HH, İnce S, Eryavuz A. Ratlarda gentamisin ile indüklenmiş oksidatif streste borun muhtemel koruyucu etkisinin dokularda araştırılması. Kocatepe Vet. J. 2017; 10: 172-179.

Lesnikovsk ZJ. 2016. Recent developments with boron as a platform for novel drug design. Exp. Opin. Drug Discov. 2016; 11: 569578.

Lewis SM. Standardization and harmonization of the blood count: the role of International Committee for Standardization in Haematology (ICSH). Eur J Haematol Suppl. 1990; 53: 9-13.

Lopez-Novoa JM, Quiros Y, Vicente L, Morales AI, Lopez-Hernandez FJ. New insights into the mechanism of aminoglycoside nephrotoxicity: an integrative point of view. Kidney Int 2011; 79: 33-45.

NseAbasi NE, Mary EW, Uduak A, Edem EAO. Haematological parameters and factors affecting their values. Agric Sci 2014; 2: 37-47.

Ozbek E, Turkoz Y, Sahna E, Ozugurlu F, Mizrak B, Ozbek M. Melatonin administration prevents the nephrotoxicity induced by gentamicin. BJU Int. 2000; 85: 742-746.

Páez PL, Becerra MC, Albesa I. Chloramphenicol-induced oxidative stress in human neutrophils. Basic Clin. Pharmacol. Toxicol. 2008; 103: 349-353.

Pahl, V.M. Culver, D.B. Vaziri, D.N. Boron and the kidney. J. Ren. Nutr. 2005; 15: 362370 .

Pedraza-Chaverri J, Maldonado PD, MedinaCampos ON, Olivares-Corichi IM, Granados-Silvestre MA, HernandezPando R. Garlic ameliorates gentamicin nephrotoxicity: relation to antioxidant enzymes. Free Radic. Biol. Med. 2000; 29: 602-611.

Saha S, Ramanthan R, Basu RA, Banerjee D, Chakrabarti A. Elevated levels of redox regulators, membrane-bound globin chains and cytoskeletal protein fragments in hereditary spherocytosis erythrocyte proteome. Eur. J. Haematol. 2011; 87: 259266.

Sayed-Ahmed MM, Nagi MN. Thymoquinone supplementation prevents the development of gentamicin-induced acute renal toxicity in rats. Clin Exp Pharmacol Physiol. 2007; 34: 399-405.

Sisk DB, Colvin BM, Merrill A, Bondadi K, Bowen JM. Experimental acute inorganic boron toxicosis in the goat: Effects on serum chemistry and CSF biogenic amines. Vet. Hum. Toxicol. 1990; 32: 205-211.

Sweetman SC. (Ed.) Martindale the Complete Drug Reference. Pharmaceutical Press 2009; London.

Vani R, Reddy CS, Asha Devi S. Oxidative stress in erythrocytes: A study on the effect of antioxidant mixtures during intermittent exposures to high altitude. Int. J. Biometeorol. 2010; 54: 553-562.

Yildirim S, Celikezen FC, Oto G, Sengul E, Bulduk M, Tasdemir M, Cinar DA. An investigation of protective effects of litium borate on blood and histopathological parameters in acute cadmium-induced rats. Biol. Trace Elem. Res. 2017; DOI 10,1007/s12011-017-1089-9. 